\title{
Bicultural Identity in Saud Alsanousi's The Bamboo Stalk
}

\author{
Areej Almutairi \\ areeejalmutairi@outlook.com \\ Faculty of Social Sciences and Humanities, \\ Universiti Kebangsaan Malaysia \\ Raihanah M.M. \\ raihanah@ukm.edu.my \\ Faculty of Social Sciences and Humanities, \\ Universiti Kebangsaan Malaysia \\ Ruzy Suliza Hashim \\ ruzy@ukm.edu.my \\ Faculty of Social Sciences and Humanities, \\ Universiti Kebangsaan Malaysia
}

\begin{abstract}
Although the world now has largely become a global village, some bicultural individuals still find it challenging to be accepted into certain societies. Building on this argument, this article analyzes the struggles faced by the bicultural character in The Bamboo Stalk (2015), a novel written by the Kuwaiti writer, Saud Alsanousi. Jose is the son of a Filipino maid and a wealthy Kuwaiti man. Upon birth, he was disowned by his paternal family and was forced to leave for Manila with his mother, to be raised in poverty. In this article, the theory of graft by Colin Richards and selected concepts on biculturalism are appropriated to explore the manifestations of the grafted individual's identity construction, demonstrating how grafting carries a negative impact in the formation of the individual's social, religious and national identities. The narrative depicts the protagonist's dilemma and identity crisis, revealing the circumstances that has led to the formation of his split identity. While the grafted individual finds it challenging to ascertain his identity that lies between two vastly different and incompatible cultures, the majority societies in the two cultures do not accept him for who he really his. This paper therefore highlights the experience of the bicultural in establishing a clear grafted identity as presented in Alsanousi's work.
\end{abstract}

Keywords: grafting; mixed-marriage; biracial; outsider; misrecognition; doubleconsciousness

\section{INTRODUCTION}

The Bamboo Stalk, an international award-winning Arabic fiction novel by Saud Alsanousi (Alsanousi, 2015a), tells the story of the bicultural Jose/Isa, who is of Filipino-Kuwaiti parentage. His parents, Rashid Altarouf and Josephine, met in Kuwait where Josephine worked as a maid in Rashid's family house. They had married secretly and when she fell pregnant, the Altarouf family insisted on Rashid giving up his wife and child. Rashid gave in to his family's demands and sent his wife and new-born back to the Philippines. The novel reflects the conservative Kuwaiti society's relationship with non-Arabs from the social, humanitarian, religious and philosophical perspectives. Although Kuwait is generally made up of a single race, religion and culture, within its society, the members are divided into classes according to their social status. The Kuwaiti society puts their authenticity and roots in high regard and preserves it as aggressively as possible. Non-Arabs are still treated in a 
civil manner, but are refrained from becoming a part of the society through marriage or relationships that would result in "tainted" bloodlines (Alsanousi, 2015b).

As evidence to support problematics of transculturalism, a study on bicultural youth and general alteration specifies "personality reconciliation" (Jackson et al., 2012) as a defensive factor in the psychological modification and well-being of bicultural people. Moreover, several studies have also identified on the components of multiracial strength including racial-ethnic adaptability (Jackson, Wolven \& Kimberly, 2013; Vasquez, 2010) and classified the usage of social capital such as language, education and job opportunities as the distinguishing elements for a bicultural to be accepted as an insider. Also, another inquiry by Mok and Morris (2012) challenges the supposition that most multiracial people feel disappointed, bitter, or distressed with their mixed-race identity or show debilitated racialethnic personalities. In another investigation on identity development of selected chick lit novels, Maryam, Raihanah and Shahizah (2017) argue that acculturation involves psychological and cultural changes. All these speculations only add to the negative presumptions about the biculturals' identity and standing.

The novel, because of its focus on an uncommon portrayal of Kuwaiti-Pinoy identity, provides insights into the obstacles faced by the bicultural character in grafting himself and finding his self-identity. Saud Alsanousi's agenda can perhaps be understood as similar to Murakami's notion of creating "a new narrative can be created by the individual in facing these realities and empowering the self to be independent" (Sheba, Ravichandran \& Shahizah, 2017, p. 78). Furthermore, an analysis addresses issues of personality reconciliation, racial-ethos adaptability or and debilitated racial-ethnic personality of the bicultural individual by identifying the rejections that he faces from both the communities in Kuwait and the Philippines. The concerns dealt here will certainly add to the body of knowledge on grafting an identity as perceived from Alsanousi's novel as well as the problems involves.

\section{LITERATURE REVIEW}

Arab writers, especially Kuwaitis write about reality, and they represent social issues of immigrants and interracial marriage in their countries. Saud Alsanousi is a member of the majority community in Kuwait, but constantly represents the minority's voice through his novels. His first novel was published in 2010 and became an award winning literary work. He later went on to win the Booker prize for his novel The Bamboo Stalk. It explores the life of a minority i.e. an individual of Filipino heritage in Kuwait. He makes use of the reality around him; many Filipinos are working in houses and hospitals in Kuwait - their relationships between employers and employees generate interesting story lines. Nadeau (2014) explains that the relationship between Kuwait and Philippines is not palpable and it affects the minority's position and treatment in Kuwait. In 2018, however, diplomatic row between Kuwait and Philippines caused tension as a result of frequent mistreatment by most of the employers (Heydarian, 2018). The character of Jose was chosen by Saud based on his observations during one of his visits to the Philippines where he noticed the vast difference between both countries in terms of customs and culture. He then decided to investigate whether an identity conflict exists within these individuals who belong to Kuwait and Philippines (Alsanousi, 2015c). 'Jose', a Kuwaiti-Filipino descendant, hence came into conception to illustrate the prevailing cultural stigma in Kuwait. For this exposé, the novel received major criticisms from the local society.

In 2015, due to rave reviews from Arab scholars, The Bamboo Stalk was translated into English and used as the base in several studies. For instance, Khawandanah's study titled "The Exile Homeland: Splintered Identity in Saud Al Sanousi's The Bamboo Stalk" (2014) 
outlines the social obstacles in Kuwait and the juxtaposition of the protagonist's self-esteem. In another study by Al Arqi (2015) entitled "Hybridity and Problematic of Identity in Gulf States Narrative" explores the challenges faced by the "Biduon" or stateless people in Kuwait. Belkhasher and Badurais (2016) in "Third Space Identity: Hybridity in Saud Alsanousi's Saq Al-Bamboo" reveals the hardship of the hybrids with distinct differences to be accepted into host land space. The study "Three Arabic Novels of Expatriation in the Arabian Gulf Region: Ibrāhīm Nașrallāh's Prairies of Fever, Ibrāhīm 'Abdalmagīd's The Other Place, and Sa 'ūd al-San 'ūsì's Bamboo Stalk', Elayyan (2016) discusses the life of the immigrants in Arab based country which is filled with challenges as the society preserves strongly their strict ideology. Al-Mutairi (2016) in "Reconciling Two Opposing Cultures: The Bamboo Stalk and the Arabic Bildungsroman" demonstrates the ethical, emotional and spiritual developments of the main character within the Kuwaiti religion and culture. McManus (2016), in her article "Scale in the Balance: Reading with the International Prize for Arabic Fiction ("The Arabic Booker")," traces the popularity and acceptance of postcolonial issues in the global perspective.

Based on these previous studies, there seems to be a lacuna in the inquiry on identity grafting of the protagonist. This article is an attempt to bridge that gap by using Colin Richards' (1997) theory to examine the struggles encountered by the bicultural in the host land in grafting his new identity. An explication of Richards' theorisation will be explained in the section below.

\section{GRAFTING AS A LENS IN ANALYZING BICULTURAL IDENTITY}

In horticulture, "grafting" entails the process of generating plants that are similar to each other. It also involves tedious physical procedures in producing a hybrid (Melnyk, 2015). The original meaning of the term has been extended to describe the process of cultural and social transplantation in a metaphorical sense. Culturally, grafting is desirable to benefit a "socially entangled" community and its accomplishment depends on the "cultivation and time" (Richards, 1997, p. 234). Grafting infers to a specific form of cultural interaction and intense cultural exploration due to the differences between the societies involved. Therefore, "cultural osmosis" (Richards, 1997, p. 235) is targeted for unplanned mixtures of cultures.

Grafting suggests an unoriginal outcome as it merges two dissimilarities to form a new identity; in such process, each party is forced to observe any hidden gap of rules in their original set of culture to allow them to find a common sphere and succeed as a society (Wirth, 2015). Richards' concept of cultural grafting focuses on the metaphorical interpretation of the term. It is a process of uneven and forced interaction between cultural entities that results in hybrid formations. It is the "rhizome" (Richards, 1997, p. 235) which takes the root of tradition with spatial limitations; therefore, the grafting process impacts the cultural identity of the society where the biculturals alter their cultural differences to form new identities, values and ideologies (Caruso, 2005). Rhizome is the space identified in the culture which allows the new identity to be grafted. It is a process of hope where the new identity anticipates to be permanent in the new environment where beliefs of acceptance are given to be a part of the others (Gail, 2005). Furthermore, the cultural changes are an unavoidable revolution where personal identities of bicultural individuals refer directly to the culture, ethnicity and language of a society (Ting-Toomay, 1999). Richards (1997) labels graft as an alternative remedy in connection to the cross-cultural exchange process because it limits the main culture. When the dominant or stronger culture adheres to an adverse ideology, it spreads into the society as a common norm. Grafting is a circumstance; when a dissimilar element is added into a culture, it affects the roots and causes alterations to the culture. The outcomes, whether positive or negative, will be apparent. The "monstrous 
misfits" as described by Richards (1997, p. 235) are hence the results of the incompatible intervention in a society. Grafting with varied levels of relations between the different cultures enables new result as the bicultural can alter their methods to fit in (Steven, 2001).

Grafting is an invasion of one cultural belief unto another which leaves a visible trace in the bicultural individual's grafted cultural identity. With so many "rhizomes", a forceful false logic of the consequences are available to be followed which appear in other cultural formations too. These rhizomes can cause the central root to be lost. This paper explains the meaning of grafting as it explores the effects of grafting in the construction of a bicultural identity. Biculturalism concept is applied in determining the success or failure of the bicultural individual's identity grafting. Grafting occurs within a space or semiosphere which is an essential sphere for the existence of heterogeneous elements to combine and enable the grafting to happen. The space helps to build a new identity that would open up new opportunities for them (Lotman, 1984) and the process is considered to be successful when the parties involved display a high degree of compatibility. When this happens, the grafted individual's conflict with social, religious and national self-identification is reduced, whilst self- and social recognitions are heightened. In cases where compatibility is not achieved, the semiosphere will work against the achievement of grafting.

Self-identification is a crucial factor in shaping the notion of self. Grafted individuals are subjected to a dual cultural identity i.e. their original culture and the adapted one. They tend to seek a semiosphere. In this semiosphere, the process of grafting takes place in which two different groups work together to achieve compatibility. In this context, the term compatibility refers to the capability of the bicultural individuals to co-exist in harmony with others, or their capability to function within another cultural system without making any modifications. The semiosphere in this regard is significant as it provides a border between two cultures and becomes the convergence zone where the grafting process takes place. However, grafted individuals often experience challenges in distinguishing their identity (Areej, Ruzy Suliza \& Raihanah, 2017) as a result of coming from two different cultures with different values and perspectives. The difficulties lie in how they label and classify themselves, in how they create their own semiosphere to link the two distinct environments, and in how the two cultures contribute to their self-identification (Markus \& Kitayama, 1991).

The merging of two cultures commonly leads to the creation of a new semiosphere in which the grafted person constructs his own identity (Poston, 1990). However, for bicultural individuals, they are caught between the "here" and "there" of two cultures, leading to the inability to form a concrete identity and eventually causing the lack of sentiments for both cultures (McLeod, 2000, p. 214). Due to this complexity, it is not easy to classify the biculturals into a particular group (Wagner, 2016) as posited by Poston (1990) who considers the situation as the formation of an identity crisis for the grafted individuals. Not having the acknowledgement of acceptance and compatibility by either society exacerbates the selfidentification crisis. Therefore, the biculturals tend to swap between their dual social identities, embodying opposite traits and doubling the behavioral pattern, leading to the creation of a binary personality.

\section{RESULTS AND DISCUSSION}

The discussion focuses on how the bicultural identity is grafted using the concepts expanded from Colin Richards's theory on biculturalism, as well as the factors that influence the bicultural individual's level of grafting. Three concepts, self- identification, social misrecognition, and cultural incompatibility are used in analyzing the grafting procedures experienced by the protagonist, Jose, in The Bamboo Stalk (2015). First, despite being half 
Kuwaiti, Jose was not recognized as one by the Kuwaiti people who are belligerently adamant in protecting the pureness of their bloodline. In fact, Jose does not have a solid stand to identify himself as either a Kuwaiti or a Filipino. Second, Jose suffers from social misrecognition. His strong Filipino features make it even more impossible for the Kuwaiti society to accept him as one of their own. Here, his features play a more prominent role than his passport identity. Finally, Jose's inability to converse in Arabic and practice Islamic rituals make him incompatible to be grafted into the Kuwaiti society.

\section{GRAFTING AND SELF-IDENTIFICATION}

In The Bamboo Stalk (2015) Jose's central conflict lies in his attempt to mediate between his two distinct biological heritages. Being half Kuwaiti and half Filipino, he is caught between two vastly contradicting cultures and social classes. Upon reaching Kuwait, his sense of selfidentification and the yearning to be identified as Kuwaiti becomes apparent:

If only my parents could have given me a single, clear identity, instead of making me grope my way alone through life in search of one. Then I would have just one name that would make me turn when someone called me. I would have just one native country. I would learn the national anthem. Its trees and streets would shape my memories and in the end I could lie at rest in its soil. I would have one religion I could believe in instead of having to set myself up as the prophet of a religion that was mine alone.

(p. 47)

In the novel, the protagonist has two names i.e. Jose in the Philippines "after the Philippine national hero Jose Rizal" (p. 3) and Isa in Kuwait. Each name bears the dilemma of coming from different cultures with their respective social/cultural/religious markers. Not only is he unable to identify himself into any one specific group, he is also not acknowledged as a member by either the Kuwaiti or the Filipino society. He faces socio-cultural issues that subject him to the reification of identity, confusion of spiritual development, and dilemma of identification. The confused self-identification indicates the conflict inside the bicultural individual's mind regarding his cultural, racial, social, national and religious identities. Cook (2014) states that the unclear self-identification pushes the individuals to divide the "inner self in an attempt to create a character that would be accepted into mainstream society" (2014, p. 1). In simpler terms, dualism is a necessity for the bicultural individual to be integrated into the majority culture i.e. by learning its language, traditions and rules. However, even after doing so, the sense of dilemma may still exist due a difference in skin color, name, or the inability to accommodate familial legacy with national cultural traditions.

The space available for grafting is not empty as it has numerous opportunities for new entries; nonetheless, the rebellious environments with eminent cultures and strict rules do not allow the grafted individuals to form their clear self-identification as grafted individuals. "the space of 'Graft', is not empty, but riven by multiply vocalized interjections and exhortations" (Richards 1997, p. 237). In The Bamboo Stalk (2015), Jose's grafted identity's complexity is highlighted in his yearning for acceptance: geographically between Kuwait and the Philippines; religiously between Islam, Christianity and Buddhism; intellectually between liberty and reservation; economically between poverty and wealth, and individually between Jose and Isa. From his narration, it is evident that he is seeking for a single, clear identity; a sense of self-identification and brotherhood among the Kuwaitis, but it is blatantly denied by the majority group. Jose's Filipino features and his Kuwaiti passport negatively affected his identity development.

In terms of religious belief, being of mixed-faith in a globalized world is commonly considered to be a good practice in terms of genetic diversity and cultural enrichment. However, it can lead to both positive and negative outcomes for the offspring since they most likely would get confused about their religious choices (Jackson, Wolven \& Aguilera, 2013). 
Generally in such cases, one of the spouses would convert into the other's religion, or the couple would raise their children to practice both religions concurrently. The latter situation does not usually create religious identity and does not affect the child's personality formation in the future. It is commonly observed among couples where the husband is a Muslim (Samuels, 2014) where confusion and loss of religious identity and assurance usually occur.

The grafting process creates space which allows intermixture of dissimilar elements to form a new identity and it is natural due to its frequency where biculturals find their selfidentification (Wirth, 2015). In The Bamboo Stalk (2015), the scenario is not favorable for the protagonist as he was not brought up to adhere to any single religion. The real dilemma for Jose is that he identifies with many faiths-Islam, Christianity and Buddhism. He wonders whether he is a real Christian because he was baptized as a child although not by his own choice: "Did my baptism make me a Christian? Did I really embrace Christianity at that ceremony, which I attended at an age when I couldn't even remember anything?" (p. 49). On another hand, he identifies with being a Buddhist as he has a constant desire to meditate with the nature around him. And despite all that, he still believes in Allah: "What about my belief in the existence of one supreme and eternal god, unbegotten and without offspring? Am I a Muslim by default?" (p. 50). Spiritually, Jose is at a loss. His father used to whisper the Muslim prayers into his ears while holding him in his arms, while his mother used to take him to a local church. Jose's praying in the church does not prevent him from going to the Seng Guan Temple, just as going to the mosque in Kuwait does not prevent him from wearing a cross around his neck. He strives for a clear religious identity by exploring three religions and he looks for similarities between those religions: "I said the prayers in a way that no else did" (p. 329). Although his practice of the religious rituals are not perfect, "that doesn't mean that I wasn't sincere when I prayed" (p. 329).

Instead of imitating or conforming to either one of his parents' religion, Jose individualizes his religious identity. Adhering to two religions creates a significant pressure, eventually leading to either the rejection of both or the duplication of the identification, which in turn leads to the development of various psychological dilemmas. However, the prevalence of single identity formation with one religion is very low in an inter-religious family. Specifically, such a condition emerges in less than one percent of children that came from dual-faith families since one religion usually prevails (Gaither, 2017). Grafting individuals show signs of dualism that is visible in certain behaviors such as behaving differently in different religious environments, obliviousness of the two behavioral lines and so on. Growing into adulthood, such children would usually choose either one of the two religions, or deny both. In Jose's case, he alternates between the faiths he practiced back in the Philippines and his father's religion.

Apart from his quest to affirm his name and religion, he also yearns for a country to belong to: "It's destiny to spend my life looking for a name, a religion and a country" (p. 50). As he landed at the airport in Kuwait, he is puzzled as to whether he should stand in line in the domestic arrival section presenting his passport that legally identifies him as a Kuwaiti, or in the international arrival section where he can line up with people who have similar features like him.

There were signs above the front of each line, some of them saying GCC Citizens and the others saying Citizens of Other Countries. I stood there, uncertain which line to stand in. Should I go to the lines where the Filipinos from my flight were standing? Or the line with the people who didn't look like me?

(TBS, p. 159)

When he decides to stand in the GCC Citizens line, the immigration officer reproves him for standing in the wrong line and asks him to move to the other line without inspecting his blue Kuwaiti passport. 
Jose's self-identification dilemma was encouraged by his mother's constant stories about his father: "My mother never stops talking about my father and Kuwait and the life that awaited me" (p. 55). Jose's father was determined to bring him back to Kuwait once he became an adult. Jose endured a poverty-stricken life in the Philippines while growing up, harboring hopes that his father will give him a better life once he moves to Kuwait: "She was paving the way for me to leave the Philippines and go back to Kuwait" (p. 17). Due to his pre-knowledge about Kuwait, he developed a patriotic sense to the country of which he had never set foot in. This sense was driven by the prevailing economic and social issues in both the Philippines and Kuwait.

The second reason for Jose's confused self-identification is due to the social mistreatment he receives in Kuwait. He reminisces about how in the Philippines, status was never an issue and everyone was treated the same: "But they don't put other people in categories in this way, outside their own circles, as either above them or below them" ( $p$. 248). Despite carrying the Kuwaiti bloodline from his biological father, he is not accepted as a member of the society. In fact, he is more accepted in the Philippines because of his physical features that are more Filipino than Arab. Apart from that, language barriers also render him unfit to be a part of the Kuwaiti community. Realizing that he belongs to neither Kuwait nor the Philippines, Jose likens himself to a shallow rooted bamboo: "Looking at the things around me, that sometimes I thought I myself was one of the trees that grew there" ( $p$. 76). One of the trees he is referring to is the bamboo tree which does not have belonging and fixed roots to any land; the tree that can grow in a new place without having a past or memory, and of which can go by different names such as bamboo, kawayan or khaizuran.

I was more like a bamboo plant, which doesn't belong anywhere in particular. You can cut off a piece of the stalk and plant it without roots in any piece of ground. Before long the stalk spouts new roots and starts to grow again in the new ground, with no past, no memory. It doesn't notice that people have different names for it - kawayan in the Philippines, khaizuran in Kuwait, and bamboo in many places.

Jose's mother wants him to be like a bamboo stalk and not like a tree that has deep roots in the Philippines, so that he could easily go back to his father's country, Kuwait and adapt. Parekh (2003, p. 12) indicated that "a global or cosmopolitan citizen, one who claims to belong to the whole world, has no political home." People have the power to control their environment and establish a private world with its own norms and values, together with a natural inclination to compartmentalize what they perceive to be of value and worth, which could be drawn from "intrinsic and extrinsic" factors. Although people can preserve their values and norms, they need to go beyond the political borders created by colonization and policies, to understand that their differences add diversity to their culture and life (Parekh, 2003, p. 5).

In the novel, Jose decides to return to his motherland and learns to live with his two identities to achieve a neutral stand in life. Jose's self-identification as a Kuwaiti is revealed when he stood and sang the country's national anthem before the start of a football match. External issue is overruled by his inner self when he manages to bring his dual selfidentification into a balanced state as a Kuwaiti in Philippines. This is clearly stated when the writer ends the novel with a football match between the Philippines and Kuwait: "Everyone clapped for joy, except for me, who felt like I'd scored an own goal” (p. 370).

\section{SOCIAL MISRECOGNITION}

Just as grafting enables plants to develop with the main plants, globalization creates an opportunity for people to travel beyond their national borders and find suitable spheres to be 
grafted (Court, 2001). In sociology, grafting is considered as a cultural breakthrough which threatens the societies' values and ideologies and aims to eliminate the various boundaries that prevent these societies from recognizing the differences and dissolving the issues (Wang, 2007). The Bamboo Stalk sheds light on the restrictive views of the Arab society and criticizes the social and religious realities in Kuwait through the lens of the rejected Jose.

Grafting is a "double-bind of ossified', it has a connection with culture where challenges occur in the "making" and "taking" (Richards, 1997, p. 236) of a new identity. A strict and conservative community goes through a "making" process in establishing their identity with traditions, beliefs and customs. The development of their norms and values are rooted deeply in their perspective and lifestyle. These values and ideals that unite the society constitute a common heritage that needs to be protected and defended. Consequently, they form a tight-knit society and deter outsiders from joining them. "taking" is the shortcut method used to penetrate an authorized community as a way to enjoy their pre-developed beliefs. "Fragile tradition" (Richards, 1997, p. 236) develops among the newly grafted individuals who are highly vulnerable to manipulation and diversion by the beliefs of others. Hence, a newly grafted individual can be perceived as an intruder who has no intention in preserving the original faith.

The collision between cultural power and grafting creates tension as it is difficult to describe the situation as either "fair exchange" or "robbery" (Richards, 1997, p. 236) of all existing traditions. The belief in a pure race and the renunciation of other races lead to a radical intransigence. Grafting entails looking for the general and the universal, whereas conservatism entails a transition from being public to private. Grafting enables marginalized individuals and minority cultures to communicate, leading to the emergence of multiculturalism featured in the core culture of the majority. Grafting a new identity in a conservative community can result in negative outcomes due to the community's strict ideology. The Kuwaiti's perception in accepting bicultural individuals is negative; the crosscultural differences can be described as "monstrous misfits" (Richards, 1999, p. 235). In the novel, the Kuwaiti community perceives Jose as a threat to the purity of their race, thus foiling Jose's attempt of reuniting with the Altarouf family. His Filipino features also hinder his acceptance into the Kuwaiti community.

Although Arabian Gulf societies have similar tribal and cultural identities, they still preserve certain unique features within their tribes e.g. the prevention of intermarriages with other tribe members even if they have the same culture and practices. The Altarouf family refuses to accept Ghassan (Rashid's close friend) although he was born in Kuwait, has pure Arabic features and comes from the same culture. His plan to marry Hind is denied because of class distinction. This shows the strict regulation that the Kuwaiti society imposes unto itself especially among the wealthy. Such social quandary also prevented Jose's grandmother from defending her Kuwaiti-Filipino grandson from social mistreatment despite her love for him.

Jose's attempts in finding a space for himself within the majority in Kuwait are unsuccessful due to a lack of common traits mainly in the aspects of religion, language, culture, ethnicity, social class and caste. These identity politics separate him from the Kuwaiti society and "becomes one of the most potent instruments of their own oppression". Such misrecognition consequently causes "self-depreciation" (Taylor, 1994, p. 26). Jose eventually gives in to the society's views about him; with a lack of self-esteem, he behaves passively and refuses to fight for his rights in the Altarouf family.

According to Richards (1997), grafting happens when one party has flawed characteristics that prevent it from joining the other party which has strong values. Taylor (1994) stated that the identity is formed and distorted by two things: the recognition and misrecognition by others. This "demand of recognitions" is "a vital human need" (25) and not 
based on the requirements made by the majority or minority party. Recognition and identity are inseparable; it is essential for humans as recognition is the acknowledgement of identity. Hence, the acceptance of others regardless of their differences contributes immeasurably to the grafting of identities (Taylor, 1994). In Jose's case, his incompatibility with the Kuwaiti society is due to his Filipino background. The Altarouf family expresses concern that his stay would result in scandals that would desecrate the family name. In this scenario, the vast differences between Jose and the Kuwaiti society deprive him from finding a clear semiosphere to graft his identity.

Upon realizing that complete social integration is impossible, Jose eventually only wants to be accepted by the majority as a grafted person with dissimilar features and not as a pure Kuwaiti. Grafting is closely linked to semiosphere which enables successful grafting process. Jose was not able to find his semiosphere in Kuwait because he was not given this space by the majority. In the grafting of plants, the scion is usually chosen based on its good characteristics which can be given to the grafted plant. Kuwait represents the scion which offers numerous benefits for Jose including wealth. However, the Kuwaiti community and the Altarouf family do not accept him or give him an opportunity to become a part of the society due to various incompatibilities such as his foreign features and inability to converse in Arabic.

Members of esoteric groups tend to bar outsiders from joining their social structure. As an outsider, Jose has a heightened awareness about his social differences from the majority and their impact on his identity. Richards (1997, p. 237) stated that the sense of national honor among the Kuwaitis together with their strict cultural beliefs have turned into a protective reaction that creates hatred towards outsiders; hence, they restrict the cultivation of grafting in their land. Richards (1997, pp. 236-237) also posited: "We know that the transnational and the global themselves are layered in a complex way, and we know that they do not consist of any simple transnational, overriding, subsuming, hegemonizing and homogenizing of difference." This suggests that even with rampant globalization, Kuwait still preserves its strong beliefs and national pride, which hinders it from accepting newly grafted individuals into its conservative circles. Whereas the community in the Philippines is open to embracing the concept of globalization and accepting people with differences. Kristeva (1993) elucidates: "The foreigner is within me, hence we are all foreigners (2), there is not a pure or single identity in us like what the Kuwaitis have claimed; we are mixed unconsciously due to the exposure of identity politics. Language and culture of others unknowingly enter into everyone's life; therefore, we are all mixed." Generally, an individual who underwent a failed grafting will remain quiet and escape from the environment, whereas the individual who had achieved successful grafting will survive and sustain in the new environment.

The idea of a collective nation as a single entity is counter argued with grafting as stated by Richards (1997): "The rainbow thus embodies a major local impulse to cultural unity, in the shape of the nation and sometimes triumphalist rhetoric of nation-building" ( $p$. 236). 'Rainbow' is a metaphor for identity politics where language, culture, race and religion unite to form and graft a new identity in a nation. Globalization together with identity politics enables the development of a new identity in a fixed and bounded nation. Another perspective argues that "a rainbow is shared hallucination, requiring only that we have the setting sun behind and mist in front of us" (p. 236). A rainbow grafting in the social context happens vaguely, slowly and gradually with the cooperation of the community and the environment once they have achieved compatibility. Ergo, Jose has failed to create a new grafted national identity in the Kuwaiti environment as suitable characteristics were absent. 


\section{GRAFTING COMPATIBILITY}

Culture is a tool that allows individuals to make sense of the behavior of others. Thus, learning a new way of living is essential in gaining social status and becoming an equal member of a society. Such norms and rules range widely from the way a person is addressed to the values that one holds. The failure to adapt to these norms and rules results in discrimination, racism and other forms of social mistreatments (Zolfaghari et al., 2016, p. 103). Discrimination faced by Jose is the result of imbalance in Kuwaiti society where he as the bicultural entity still finds himself in the unfamiliar ideology of Kuwait and struggles to graft his identity with the community. The anatomical mismatch between the grafting parties is mentioned by Benet-Martınez and Haritatos (2005) that cultural conflicts can result in discrimination or racism as dissimilarities become obvious in both cultures. Therefore, compatibility or at least some similarities between the grafting parties are required to achieve a desirable outcome and to minimize unfavorable results such as the development of discrimination and alienation later in life. Thus, biculturals from incompatible grafting environments face specific challenges that hinder the grafting of their identity such as having to deal with cultural and religious variations, encountering unhelpful relatives, handling conflicts, and losing their original identity.

Grafting is a natural process to produce a new outcome i.e. by merging different environments, aspects and specialties (Goldschmidt, 2014); however, in a general social perspective, there is a narrow understanding of the concept whereby grafting is considered to be useful only if the other parties are of similar or higher status. In actuality, positive results can be obtained regardless of the participants' status level. However, in the novel, the Arabs do not consider the Filipinos as their equal, which hinders Jose's acceptance into the society. Jose's rejection by the Kuwaiti society is also partly due to his physical features which he has no control over: "I had so many names, but my face stayed unchanged" (p. 189). Using identical features as the basis for a smooth grafting process is a practice of racism.

In the novel, there are numerous displays of racism and persecution against Jose due to his Filipino background such as his father carrying him out of the garage door when he left his grandmother's house, his departure to the Philippines with his mother, and him being forced to live in the servants' suite instead of the family house: "I watch my family with a heavy heart from my exile in the annex" (p. 236). Later he had to leave the Altarouf's house to live in his own apartment and the final exit was when Kuwait shuts its doors on him. Even his family name has a symbolic meaning - Altarouf is a Kuwaiti term for the trawl. This depicts the surly society that Jose had to face, including his whole family who had colluded against him. Jose's narrations of "if only I could be 'the Filipino' in Philippines" (p. 4) and "if only my parents could have given me a single, clear identity" (p. 74) illustrate his deep desire to take hold of his long-lost identity.

\footnotetext{
“Aren't you going to come in and wish grandmother a happy Eid?" she asked me. "After everyone's gone? Once she is sure no one will see the face that brings shame on the family?" I said. The words just slipped out of my mouth, involuntarily. I was pointing at my own face as I spoke. "Khawla!" I said angrily. "Why do they treat me this way?" She was still smiling, though there was no longer anything to smile about. "It's not easy, Isa," she said, looking at the ground.

(p. 246)
}

The excerpt above illustrates both the struggles of the bicultural individual who is at the receiving end of racism, and the difficulties of the other parties to change their racial profiling of other cultural groups. Taylor (1994) emphasizes that the politics of "redistribution" aggravates the practice of inequality towards the minorities by universalizing the dominant group. As a result, extreme conditions encourage the bicultural to experience misrecognition. Recognition distribution is deeply rooted in social, economic and political 
pressures that exploit marginalized individuals and deprive them of social justice. When a society accepts and agrees to something unusual, it is called "false consciousness" as it hinders the progress of social justice, as stated by Fraser (1996, pp. 4) that "some proponents of redistribution reject the politics of recognition". In Jose's case, he received no equal recognition as a member of the Altarouf family which deeply affected his identity.

Besides external racism, Jose is also subjected to internal racism by his family. His aunt bluntly questions his religious practices and asks him to accept his unfortunate fate to get him to leave the country:

\footnotetext{
"Be strong believer. Accept your faith. Be content with what God has decreed for you," she continued.

"God?" I asked.

But when he shows his sister the Prophet's saying that "All mankind is from Adam and Eve. An Arab is not superior to a non-Arab nor a non-Arab superior to an Arab" she replies that "this has nothing to do with religion" (p. 374). This clearly reveals how the Kuwaiti society, despite practicing the rituals of Islam, does not abide by its principles and fails to adhere to the religion's actual teachings.

\section{CONCLUSION}

Based on the analysis of The Bamboo Stalk (2015), it can be concluded that the character of Jose demonstrates an example of an attempt for identity grafting and it is incorporated to construct the bicultural grafting of the Muslim young adults' identity. The examples of identity grafting through Jose, display genuine manifestations of the two semiospheres in which the collective emblem of grafting the bicultural identity is formed and failed. Jose is totally fractured and unable to identify who he is and how to classify himself nationally, culturally, socially and religiously.

In terms of social recognition, he fails to acquire any acknowledgement from the Kuwaiti society. In cultural identity grafting, the compatibility of the two grafting parties is required to enable the achievement of a desirable grafted outcome so as to minimize unfavorable results and to avoid conflict between the two cultures which could lead to the development of discrimination and alienation later in life. Richards' (1997, p. 235) statement that "all the currently crucial question around cultural power" explains that the grafting process is dominated by the majority culture in order to achieve successful grafting. Hence, the primary community has to cooperate without distinguishing dissimilar identical features and origins in a new person.

The "speak of alienation" (p. 235), an unfriendliness occurs when the cultural power puts great pressure on the grafted person to be accepted into their community. A successful or failed grafted person experiences a sense of change physically and psychologically due to "being remapped" (p. 235) and the grafted individual has to adapt with the changes. The cultural importance of the majority hence becomes visible. It is human nature to avoid and disfavor people who are unalike. It is unavoidable where the face, feature, language, religion, and culture have noticeable effects in establishing social relationships and in determining how people deal with others. Saud Alsanousi presents the voice of the minority in Kuwait where the land restricts within their identity from permitting the biculturals by showing the image of Kuwaiti's unconscious mind in treating the others. The novel proves that receiving recognition into the graft junction completes the grafting process. The present discussion, contributes to the bicultural's grafting new identity in critical mono-cultured society as presented in Saud Alsanousi's work. 


\section{REFERENCES}

Al Arqi, R. (2015). Hybridity And Problematic Of Identity In Gulf States Narrative. European Journal of English Language and Literature Studies. 3,68-88.

Almutairi, A, Ruzy Suliza Hashim \& Raihanah, M. M. (2017). Grafting eco-diasporic identity in Randa Abdel-Fattah's selected novels. GEMA: Online Journal of Language Studies. 4, 179-190.

Al-Mutairi, R. (2016). Reconciling Two Opposing Cultures: The Bamboo Stalk and the Arabic Bildungsroman. Arab World English Journal. 7, 358- 367.

Alsanousi, S. (2015a). The Bamboo Stalk. Qatar: Bloomsbury Qatar Foundation Publishing.

Alsanousi, S. (2015b). In conversation: Saud Alsanousi talks about The Bamboo Stalk. The Arab Weekly.

Alsanousi, S. (2015c). Interviewed by Leber, B. on What 'Bamboo Stalk' Is Really About and Why Some Kuwaitis Disapprove. Arabic Literature and Translation.

Belkhasher, K. \& Badurais, R. (2016). Third Space Identities: Hybridity in Saud Alsanousi's Saq Al-Bamboo. Al-andalus journal for humanities \& social sciences. 13(10), 5-36.

Benet-Martinez, V. Haritatos, J. (2005). Bicultural identity integration (BII): Components and Psychosocial Antecedents. Wiley Online Library.

Caruso, H. (2005). Art as a Political Act: Expression of Cultural Identity, Self-Identity, and Gender by Suk Nam Yun and Yong Soon Min. Journal of Aesthetic Education. 39 (3), 71-87.

Cook, B. (2014). Double Consciousness. McNair Scholars Journal. 15, 1-18.

Court, P. (2001). The Impact of 'Globalization' On Cultural Identities. Retrieved February 23, 2019 from http://www.pass.va/content/dam/scienzesociali/pdf/acta7/acta7morande.pdf

Elayyan, H. (2016). Three Arabic Novels of Expatriation in the Arabian Gulf Region: Ibrāhīm Nașrallāh's "Prairies of Fever", Ibrāhīm 'Abdalmagīd's "The Other Place", and Sa'ūd al-San 'ūsī’s "Bamboo Stalk." Journal of Arabic and Islamic Studies. 16, 85.

Fraser, N. (1996). Social Justice in the Age of Identity Politics: Redistribution, Recognition, and Participation. Stanford: Stanford University.

Gail, M. (2005). Tsugiki, a Grafting: The Life and Poetry of a Japanese Pioneer Woman in Washington. Columbia Magazine. 19(1), 29-39.

Gaither, S. (2017). The Multiplicity of Belonging: Pushing Identity Research Beyond Binary Thinking. Retrieved March16, 2019 from

https://sites.duke.edu/dukeidlab/files/2017/11/MultipleIdentities.SelfIdentity.Gaither2 017.pdf

Goldschmidt, E. (2014). Plant grafting: New mechanisms, evolutionary implications. Frontiers in Plant Science. 5, 1-9.

Heydarian, R. (2018). Why Duterte banned workers from going to Kuwait. What is behindthe escalating diplomatic crisis between the Philippines and Kuwait? Retrieved from https:/www.aljazeera.com/indepth/opinion/duterte-kuwait-philippines-diplomaticcrisis-180503065733569.html

Jackson, K. F., Wolven, T. \& Aguilera, K. (2013). Mixed Resilience: A Study of Multiethnic Mexican American Stress and Coping In Arizona. Family Relations. 62, 212-225.

Jackson, K. F., Yoo, H. C., Guevarra, R., Jr. \& Harrington, B. A. (2012). Role of Identity Integration on The Relationship Between Perceived Discrimination and Psychological Adjustment of Multiracial People. Journal of Counseling Psychology. 59(2), 240250 . 
Khawandanah, N. (2014). Splintered Identity in Saud Alsanounsi's The Bamboo Stalk. Conference: Language: The Beacon of Culture and Thought. Saudi Arabia: Effat University, November.

Kristeva, J. (1993). Nations without Nationalism. New York: Columbia University Press.

Lotman, Juri. (1984). On the Semiosphere. Signs Systems Studies. 33(1), 206-229.

Markus, H. R. \& Kitayama, S. (1991). Culture and The Self: Implications for Cognition, Emotion, and Motivation. Psychological Review. 20, 568-579.

Maryam Mazloomian, Raihanah M.M. \& Shahizah I.H. (2016). Love Relationships and Identity Development in Selected Asian American Chick Lit. GEMA Online ${ }^{\circledR}$ Journal of Language Studies. 16, 155-171.

McManus, A. (2016). Scale In The Balance: Reading With The International Prize For Arabic Fiction ("The Arabic Booker"). International Journal of Middle East Studies. 48, 217-241.

McLeod, J. (2000). Beginning Postcolonialism. Manchester: Manchester University Press.

Melnyk, C, et al. (2015). A Developmental Framework for Graft Formation and Vascular Reconnection in Arabidopsis thaliana. Current Biology. 25(10), 1306-1318.

Mok, A. \& Morris, M.W. (2012). Managing Two Cultural Identities: The Malleability of Bicultural Identity Integration as A Function of Induced Global or Local Processing. Personality \& Social Psychology Bulletin. 38(2), 233-246.

Nadeau, K. (2014). A maid in servitude: Filipino domestic workers in the Middle East. Migration Letters. 4(1), 15-27.

Parekh, B. (2003). Cosmopolitanism and Global Citizenship. Review of International Studies. 29, 3-17.

Poston, W. S. C. (1990). The Biracial Identity Development Model: A Needed Addition. Journal of Counseling and Development. 69(2), 152-155.

Richards, C. (1997). Reflections: Curator, Graft. In Colin Richards \& Okwui Enwezor (Eds.). Trade Routes: History and Geography (pp. 235-237). Johannesburg: Thorold's Africana Books.

Samuels, G. M. (2014). Multiethnic and Multiracialism. In L. E. Davis \& T. Mizrahi (Eds.), Encyclopedia of Social Work (20th ed.). NASW Press and Oxford University Press.

Sheba D. Mani, Ravichandran V. \& Shahizah I. (2017). Japanese Dichotomies and the Individual Identity in Haruki Murakami's Colourless Tsukuru Tazaki. GEMA Online ${ }^{\circledR}$ Journal of Language Studies. 17, 77-88

Steven G. (2001). The precision of persimmons: Hybridity, grafting and the case of Li-young Lee. Lit: Literature Interpretation Theory. 12(1), 1-23.

Taylor, C. (1994). The Politics of Recognition. Retrieved March 9, 2018 from http://elplandehiram.org/documentos/JoustingNYC/Politics_of_Recognition.pdf

Ting-Toomey, S. (1999). Communicating across cultures. New York: Guilford Press.

Vasquez, J. M. (2010). Blurred borders for Some but Not "Others": Racialization, "Flexible Ethnicity," Gender, and Third-Generation Mexican American Identity. Sociological Perspectives. 53(1), 45-71.

Wagner, C. (2016). Migration and the Creation of Hybrid Identity: Chances and Challenges. $\begin{array}{llll}\text { Retrieved January } & 12, & \text { from }\end{array}$ http://www.orthodoxpeace.org/hss/proceedings/volume02/v02116wagnerc.pdf

Wang, Y. (2007). Globalization Enhances Cultural Identity. Retrieved April 4, 2019 from https://web.uri.edu/iaics/files/09-Yi-Wang.pdf

Wirth, U. (2015). Copy \& Paste: Grafting as a Model for Copy and Culture. Retrieved April 9, 2019 from https://www.academia.edu/13757120 
Zolfaghari, B, et al. (2016). How Do We Adopt Multiple Cultural Identities? A Multidimensional Operationalization of the Sources of Culture. European Management Journal. 34, 102-113.

\section{ABOUT THE AUTHORS}

Areej Almutairi is a Ph.D candidate at the School of Language Studies and Linguistics, Faculty of Social Sciences and Humanities, Universiti Kebangsaan Malaysia (UKM). Her area of interest is Muslim diasporic literature.

Raihanah M. M. is an Associate Professor of literary studies at the Faculty of Social Sciences and Humanities, Universiti Kebangsaan Malaysia. Her research interests include Literary Studies, Minority Fiction, and Muslim Diaspora.

Ruzy Suliza Hashim is Professor of Literature at the School of Language Studies and Linguistics, Faculty of Social Sciences and Humanities, Universiti Kebangsaan Malaysia (UKM). She is the Deputy Director for Planning, Operation \& Quality at Centre for Research and Instrumentation Management (CRIM). 